\title{
Colorectal Enterochromaffin Cell Serotonin-Producing Neuroendocrine Tumor
}

National Cancer Institute

\section{Source}

National Cancer Institute. Colorectal Enterochromaffin Cell Serotonin-Producing

Neuroendocrine Tumor. NCI Thesaurus. Code C96162.

A well differentiated neuroendocrine tumor that arises from the colon or rectum and produces serotonin. 